Revista Eletrônica Geografar, Curitiba, v. 2, Resumos do VI Seminário Interno de Pós-Graduação em Geografia, p. 67-67. Junho/2007

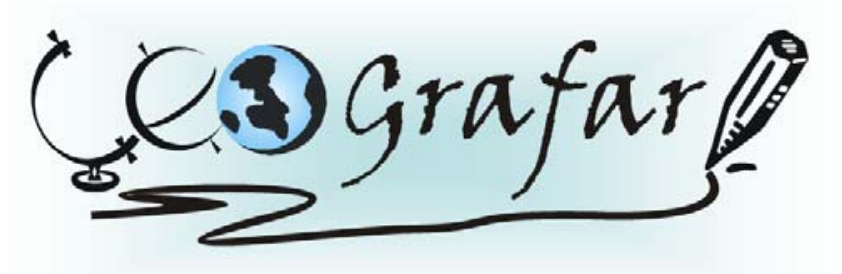

Revista Eletrônica do Programa de Pós-Graduação em Geografla - UFPR

\title{
OS PROFISSIONAIS DO TURISMO E AS REPRESENTAÇÕES SOCIAIS: AS FRAGMENTAÇÕES DO ESPAÇO NAS SOCIEDADES MODERNAS
}

\author{
Silvana do Rocio De Souza ${ }^{1}$
}

Esta pesquisa discute as fragmentações do espaço e da cultura nas sociedades modernas investigando as relações existentes entre os profissionais do turismo, o espaço e a sociedade, desvelando estas relações. Considera a atividade turística um fenômeno social e que necessita ser estudado através das inter-relações entre as ciências, em especial com a geografia. Considera também, o caráter espacial do turismo inserido na nova dinâmica social onde as categorias de análise espaço e tempo são entendidas como categorias científicas que permitem explicitar a realidade. A compreensão destas categorias permite interpretar os valores e os signos de uma sociedade, entendendo que estes signos numa realidade concreta podem estar refletindo uma outra coisa que não aquela concretamente representada. Apresenta uma nova proposta de olhar a cultura e entender as viagens e os deslocamentos através da percepção do espaço em distintos tempos. Compreende as representações sociais que aparecem no espaço analisando os aspectos geográficos, econômicos, sociais e culturais como reflexo das relações ali existentes. Concebe as relações humanas como fruto de suas experiências no espaço, no tempo e nas relações de uns com os outros. Analisa a espacialidade que os cursos de graduação em turismo ocupam no Estado do Paraná, sua inserção geográfica e social. Investiga as estruturas curriculares destes cursos e suas contribuições para valorização da cultura e da sociedade. Apresenta proposições alternativas que venham contribuir para a compreensão das representações sociais, a partir da compreensão do espaço, do tempo, do território e da cultura.

Palavras chave: turismo, representação, espaço.

1Doutoranda em Geografia - UFPR - email:silvanarcsouza@hotmail.com

Orientador: MIGUEL BAHL 